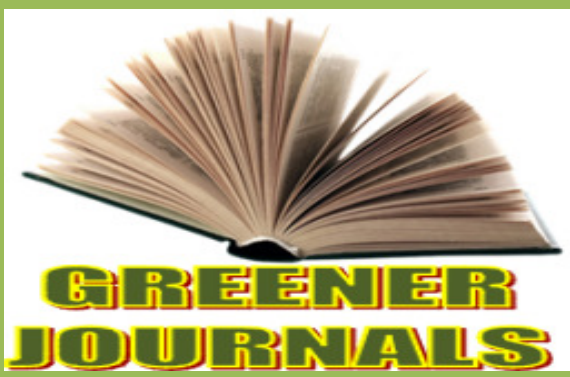

Greener Journal of leconomicsand Accountancy

ISSN: 2354-2357

Effect of Commercial Bank Loans on Financial Performance of Savings and Credit Co-Operative Societies in Kisumu, Kenya

By

Alecia, Elizabeth Ochido Okungu Robert Kisavi Mule Destings Nyongesa Fredrick Onyango Aila Dr. Gideon Momanyi Asewe Stephen Ogut Dancan Mayieka Onchonga Justine Oyagi Omoke Japhet Korir Michael Munene Muchoki 


\title{
Effect of Commercial Bank Loans on Financial Performance of Savings and Credit Co-Operative Societies in Kisumu, Kenya
}

\author{
Alecia, Elizabeth Ochido Okungu ${ }^{1}$, Robert Kisavi Mule ${ }^{2}$, \\ Destings Nyongesa ${ }^{3}$, Fredrick Onyango Aila ${ }^{* 4}$, \\ Dr. Gideon Momanyi ${ }^{5}$, Asewe Stephen Ogut ${ }^{6}$, Dancan Mayieka \\ Onchonga $^{7}$, Justine Oyagi Omoke ${ }^{8}$, Japhet Korir ${ }^{9}$, \\ Michael Munene Muchoki ${ }^{10}$ \\ ${ }^{1,2,6,7,9,10}$ Department of Accounting \& Finance, School of Business and Economics, Maseno University, \\ Private Bag, Maseno, Kenya. \\ ${ }^{3,5}$ Department of Economics, School of Business and Economics, Maseno University, \\ Private Bag, Maseno, Kenya. \\ ${ }^{4,8}$ Department of Marketing and Management, School of Business and Economics, Maseno University, \\ Private Bag, Maseno, Kenya. \\ *Corresponding Author's Email: fredrick.aila@gmail.com
}

\begin{abstract}
Savings and credit cooperative societies' core business is mobilizing savings from members, and then providing them with credit at affordable interest rates. However, SACCOs have received stiff competition from commercial banks, as a result, many SACCO members have moved to borrow from the commercial banks. If this trend continues unchecked, the SACCO societies might collapse. Hence, the need to find out how commercial bank loans have affected the financial performance of Savings and Credit Co-operative societies. The general objective of this study was to investigate the effect of personal loans offered by commercial banks on the financial performance of savings and credit cooperative. The specific objectives of the study were; to determine the effect of commercial bank loans on the savings and lending volumes of SACCOs, to investigate the benefits individual members have gotten from the competition between commercial banks and SACCOs and finally to identify the factors that cause SACCO members to borrow money from other financial institutions. The research adopted a case study design. Data was collected by use of structured questionnaires, to collect primary data. The literature reviewed, published financial statements and reports formed the basis of secondary data. Data was analyzed using descriptive statistics. The study may be of benefit to the management of savings and credit cooperative societies as it highlighted the effect of the loans offered by commercial banks on the growth as well as financial performance of SACCOs. It was found that SACCOs have not been grossly affected by commercial bank loans, since a $p$ value of 0.004 was obtained during the paired $t$ test. This was also confirmed by indicators such as membership, savings and amount of loans granted which increased over the years. It was further established that members benefited from the competition between banks and SACCOs since $\mathbf{4 5 . 1 4 \%}$ agreed and $6.49 \%$ strongly agreed that it was now easier to obtain loans from SACCOs. However $60 \%$ of the respondents reported that they were limited by the pro rata requirements by the SACCOs. Following these findings, the researcher thus recommended that the government should come up with policies to protect SACCOs and offer equal opportunity for acquiring funds.
\end{abstract}

Keywords: Commercial Bank Loans, SACCOs, Repayment Period, Terms of borrowing, Kenya.

\section{INTRODUCTION}

Kenya has had an impressive economic growth over the last five years and the stage is set for the actualization of vision 2030 hinged on the economic, social and political pillars. The economy has been performing well but post-general election violence following disputed presidential election results of 2007 have shown that the political and social pillars have to be prioritized to enable the economic pillar to be firmly re-established. In the year 2006, GDP growth was $6.4 \%$ while in 2007 , there was $7 \%$ GDP growth. The $7 \%$ growth was stimulated by sustained fiscal and monetary policies, a resilient private sector (including the informal sector) and prosperous trading partners. The overall average annual inflation rate stability with the average lending interest rate being $13.32 \%$ in 2007, compared to $13.70 \%$ in 2006 . The 91 days Treasury bill rate was $6.87 \%$ in 2007 (GoK, 2008). The impressive economic growth rate is now attracting and creating confidence in the banking sector thereby 
making the industry retrace and find its footsteps to the rural areas where commercial banks withdrew their services in the mid-1990s.

The withdrawal by the commercial banks from the rural Kenya in the1990s was a boon and a blessing in disguise to the urban and other rural related SACCOs. It created an opportunity for the sub-sector to establish a strong foothold in savings mobilization and credit provision at affordable interest rates. Today, the relatively strong economic growth as compared to that of the early 1990s has generated more than enough liquidity to the commercial banks. They now have to seek for opportunities in the economy to invest the excess cash. The banks have, therefore, identified a number of investable alternatives among them the SACCO societies.

The commercial banks' acquisition of clients in the co-operative sub-sector has created ripples in the business. The electronic and the print media have described this as "Banks battle it out for potential customers" (GoK 2004). According to Central Bank statistics, commercial banks at the beginning of 2008 were holding Kshs. 682 million. Around two million Kenyans out of a total workforce of 15 million in the formal, informal and farming sectors hold bank accounts today. Over half of these customers are with Equity Bank and Co-operative Bank (GoK, 2008). The SACCOs on the other hand served 13 million members with Kshs. 210 million in deposits and advanced loans worth Kshs. 150 million as at 31/12/2007. SACCOs serve 17 per cent of Kenya and have grown at an average of 20 per cent per year over the last five years (GoK, 2008).In Kenya, cooperative movements is found in agriculture, transport, housing, financial service, and handicraft. The history of cooperation movement in Kenya dates back to 1908 when a group of white settlers established the first agricultural co-operative in Kipkelion Township, Kericho County for the purpose of marketing their produce (GoK, 1986).

The SACCO Bill 2008 tabled in Parliament prohibits SACCOs from engaging in foreign exchange operations wholesale, retail trade, underwriting and placing securities. Most SACCO Societies rely on wholesale business to get revenue that earns dividends to members (GoK, 2008). The Bill is intended to regulate the sector which had savings up to Kshs. 210 million as at the end of December 2007. SACCO serves 17 per cent of Kenyans and has grown at an average of 20 per cent the year 2003 to 2007 (KUSCO, 2008). The Bill promises to bar SACCO from expanding membership by taking deposits from non-members which could undercut membership at a time when the societies are struggling to keep their members. Kenya's SACCO has opened up to membership outside their traditional bases in a bid to raise capital for funding new investments. Competition from banks and pyramid schemes has whittled down SACCO membership.

\section{Operations of Saving s and Credit Co-operatives in Kenya}

Savings and credit co-operatives are part of the financial system in Kenya. The other participants in this sector are commercial banks, non-banking financial institutions, building societies and insurance companies. Savings and credit co-operatives receive savings from members in the form of shares or deposits and from this created pool; they serve the credit needs of members through personal loans. The principle underlying lending by savings and credit co-operatives is that not every member will request for a loan at the same time (Ongore, 2001). Savings and credit co-operatives are not foreign to Africa. There existed indigenous savings associations known by different names ("ekubi" in Ethiopia, "sanduki" in Sudan, "enusi in Nigeria, "chilimba" in Zambia and so on) but all of them consisted of simple organizations in which savings and credit were administered on rotating basis by the members. Examples of such organizations in Kenya include the women's "mabati" or "makuti" groups. These groups meet at intervals (weekly, monthly and so on) and each of the members contribute a fixed amount.

Loans to members are granted for almost any productive purpose but the upper limit cannot presently exceed four times the members' shares or deposits and with a maximum repayment period of 48 months. The security for loans is usually composed of the member's own savings in addition to two or three guarantors whose considered shares and those of the members must exceed the amount of loan applied for. This is to ensure that in case of default, the loan can be recovered fully from the shares of the member and those of his/her guarantors (circular by Commissioner of Cooperatives, 1997). Repayment of loans is usually made by installments through salary deductions. The maximum rate of interest charged on loans is $1 \%$ per month on the outstanding balance, which translates into annual rate of $12 \%$ p.a. although a lower rate is allowable. Members can also repay outstanding loan in order to qualify for another loan or where the member has left the common bond of the society (Burnett, 1997).

Limited number of studies has been carried out which compare financial performance of SACCO's, under strict competition with commercial banks in Kenya. However, some studies have been done in comparison of performance of enterprises under government control. Ogeto (1994) did a comparison of financial performance of public and private companies. His findings were that the financial performance of private sector was much better than the public. Kikeri and Nell (1989) asserts that there is a considerable empirical evidence to support the contention that private sector managers out-do public sector managers. He gives higher rates of return on total assets employed in private sector than those prevailing in roughly comparable undertakings in the public sector. In Thailand for example, in the period $1983-1989$, the public sector rate of return was 2.75 per cent and 3 per cent, while the private sector rate was 3.78 per cent. In South Korea, in the early 1980s, the public rate was 9.87 per cent, while the private sector recorded 27.4 per cent. In India from the late 1960s to mid-1980s, the public sector rate of return was between 2 and 3 per cent, while the private had between 9 and 12 per cent (Ogeto, 1994). 
Makoba (1993) looked at public control and public enterprise performance in Sub-Saharan Africa: The Case of Tanzania and Zambia. He used financial profitability and capacity utilization as useful indicators of public performance since both criteria are central to the goals of commercially oriented enterprises. The study that the absence of political interference and operational autonomy of foreign management facilitated the high level of financial profitability observed among foreign managed enterprises in both Tanzania and Zambia. Muturi (2000) in Kenya carried out a study on performance and sustainability of formal micro -finance institutions: A case of Nairobi. His study also looked at measures put in place by micro-finance Institutions towards achieving sustainability in a bid to increase their outreach of credit facilities to small and medium enterprises. Various categories were covered namely Non-Governmental Organizations (NGOs), Development Finance Institutes (DFIs), and Commercial Banks. The study findings were that micro- finance institutions have a huge role to play towards poverty alleviation through credit accessibility. However, factors such as limited financial resources, delinquent loans, lack of management information systems, wide geographical coverage, poor research and development departments among other factors were identified as hindrance to the role of financial institution.

Kithuka (2004) examined whether Ukaguzi SACCO experienced delay or non- remittance of SACCO funds by employer and its effects on the ability to pay loans to members to compete with traditional banks. The study shows that Ukaguzi SACCO does not have serious problems of SACCO funds. The mild delay by a few employers has not affected performance of the SACCO.

Mungai (2006) carried out study on the effects of competition on provision of financial services by Mwalimu SACCO, a case of Thika District. His findings were that Mwalimu SACCO has suffered a blow from competition that has intensified in the recent years; some of her members have found other avenues for meeting their financial obligations and thus has affected the SACCO's annual incomes. The researcher further found that teachers in Thika District are not willing to leave Mwalimu SACCO because of its stability. The competing institutions with Mwalimu SACCO have managed to lure a few members. The situation can change if the institutions in question prove otherwise.

Oyoo (2000) carried out a study on financial performance of selected savings and credit co-operative societies in Nairobi before and after deregulation. His findings were that the revenues earned through bank deposits, interest charged on loans and income from investments increased after deregulation and that proper investment evolution criteria were put in use. In view of the above researches, there was need for more work and research to be carried out to clearly fill the knowledge gap as regards the effect of commercial banks loans on financial performance of SACCOs in Kenya.

\section{Statement of the Problem}

Competition is a given phenomenon in today's financial service industry environment; determining the most effective ways of competing and managing the competition can be a real challenge. Commercial banks and other financial institutions now target salaried employees who are SACCO customers. SACCOs, in the process, have had a significant loss of their members to the commercial banks and other financial institutions. The commercial banks are aggressively campaigning to attract many SACCO members to borrow from them. The performance of SACCOs is dwindling and this has been attributed to competitive pressures. For example the loans applicants' annual report of Mwalimu SACCO in the years 2006 and 2007, the applicants for normal loans were 20,890 and 12,764 respectively registering a decline of 8126 applicants or about 39 percent. The decline may be an indication that SACCO members outsource for credit facilities from other financial institutions.

According to the Annual reports of KUSCO (2008) apart from the commercial banks, the Pyramid Schemes became a challenge to the SACCOs, some members borrowed loans from SACCO and other financial institutions, promised to get three times the amount invested into the Pyramid Scheme. The SACCO charges $1.7 \%$ interest per month on loan on reducing balance while commercial banks charge about a fixed rate of $18 \%$ per month yet SACCO members continue to seek credit facilities from commercial Banks consequently reducing their savings and borrowing capacity. If the trend continues the SACCOs are likely to collapse. The effect of this completion and how the competition has affected the financial performance of SACCOs had not been investigated. This study addressed this gap.

\section{Objectives of the Study}

The purpose of the study was to investigate the effect of commercial bank loans on the financial performance of savings and credit cooperatives in Kisumu City, Kenya. Specifically, the study sought to:

i. Determine the effect of loans offered by commercial banks on the savings and lending volumes of SACCO in Kisumu City.

ii. Investigate the benefits individual members have gotten from the competition between commercial banks and SACCOs in Kisumu City.

iii. Identify the factors that cause SACCOs' members to borrow money from other financial institutions in Kisumu City. 


\section{Research Questions}

i. To what extent has the emergence of commercial banks loans affected the SACCO savings and lending volumes in Kisumu City?

ii. What benefits have the SACCO members gotten from the competition in Kisumu City?

iii. What factors have caused SACCO members to borrow money from other financial institutions in Kisumu City?

\section{Conceptual Framework}

The researcher looked at the interest on loan, repayment period, number of applicants, terms of borrowing as the independent variables and specific unique products as the intervening variable that influence the performance of the SACCO.

Independent Variables

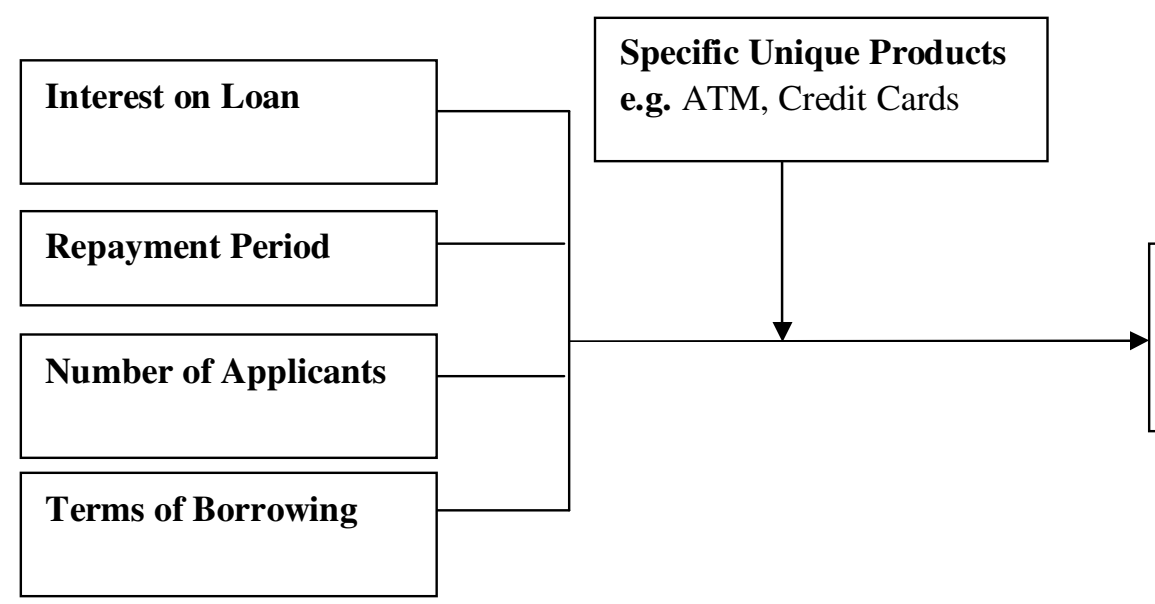

Dependent Variables

Figure 1: Relationship between Commercial Bank Loans and Performance.

The relationship above shows the dependent variable, financial performance as affected by the independent variables, interest on loan, repayment period, number of applicants and terms of borrowing. First is Interest on loan: that SACCO members look at before borrowing, if the rates are favorable then more members are likely to take up the loans. The more members take loans, the better the financial performance will be and vice versa.

Secondly, terms of borrowing: SACCOs offer loan probation period in which a member cannot apply immediately after completing development loan. SACCOs requires guarantors before the loans are processed and two- thirds of salary retained by the member. The commercial banks do not require guarantors from the customers before processing the loan other than the three most current pay slips. The banks no longer ask their customers collateral for personal loans. The commercial banks make the funds available on demand by making loan processing very fast. Therefore favorable terms of borrowing will positively affect the financial performance of the institution.

Third is, loan repayment period: Commercial banks allow the repayment period up to seventy two months whereas SACCOs allows sixty months maximum repayment period. Repayment period can encourage or discourage members from taking up loans. For instance, if the repayment period is long, then more members may be encouraged to go for loans and this will lead to a great turnover at the end of the day.

Lastly, number of loan applicants: the more the loan applicants the better the performance is likely to be. If the number of applicants is high, it means that a large number of loans will be issued and this will definitely lead to better performance in terms of share capital and turnover.

\section{METHODOLOGY}

The researcher utilized a case study research design. This gave numeric description of a part of the population called the sample on the basis of the data which was collected. Bell (1989) says a case study aims at obtaining information that can be analyzed, patterns extracted and comparisons made for the purpose of clarification and provision of basis for making decision. This was appropriated to enable the researcher present data in a meaningful form, thus help to offer ideas for further probe and research and help make certain simple decisions. The study was carried out in Kisumu City, located in the Nyanza Region in Kenya. It is bordered by Busia town to the north, Kakamega town to the north east, Kericho town to the east and Kisii town to the south. Major roads 
lead from the city to these towns. The SACCO studied is located in Kisumu City. The study targeted 5000 members of the selected SACCO. The subjects of the study were drawn from one SACCO in Kisumu City. The targeted respondents were SACCO management and its members so as to obtain elaborate information.

A sample size of 370 respondents was used. It was determined and purposely selected according to Mugenda and Mugenda (1999), who postulates that $10 \%$ sample size of 300 and above is adequate whereas a population less than 300 requires a sample size of $30 \%$. The researcher collected data by use of structured questionnaires. One set of questionnaire was administered to the SACCO management staff and another set of questionnaire administered to the SACCO members. The researcher personally administered the questionnaires to the respondents. Secondary data was gathered from journals, periodicals, Magazines and newspapers.

A questionnaire is an important device in gathering data from widely scattered sources (Marion, 1999). Since the data was gathered from a widely spread sample that is, management staff and members from Mwalimu SACCO in Kisumu City, it was necessary to use questionnaires as a tool for data collection. Formulated questionnaire was pre-tested to establish its validity before it was administered to the respondents. Questionnaire was structured to enhance research objectivity. This allowed for the findings to be pre-coded and analyzed statistically (Sudman and Bradburn, 1982). Both closed and open-ended questions were included in the questionnaires to give respondents an opportunity to freely comment on given issues.

Bio-data of the SACCO member's respondents was established. The quantitative data was analyzed using descriptive statistics to establish frequency and the number respondents in each factor tested. Qualitative data methods allowed the researcher to study selected issues in depth and in detail. To establish association of the respondents' demographic status to their views on effect of commercial banks on their SACCO, a chi-square test, was used to get views on association particularly the SACCO members views on effects of Commercial banks. Correlation analysis was then done on respondents' financial position to their views on commercial banks' lending. Data was presented in figures, tables, graphs and pie charts.

\section{RESULTS}

\section{Socio-Demographic characteristics of the respondents}

Data from the financial reports of the selected SACCO (KUSCO, 2007, 2010) together with data collected through the questionnaires were used for analysis and report generation. Statistical package for social science software version 12.0 and Stata I/C version 11software were used for the analysis. Data was presented in tables, charts and graphs.

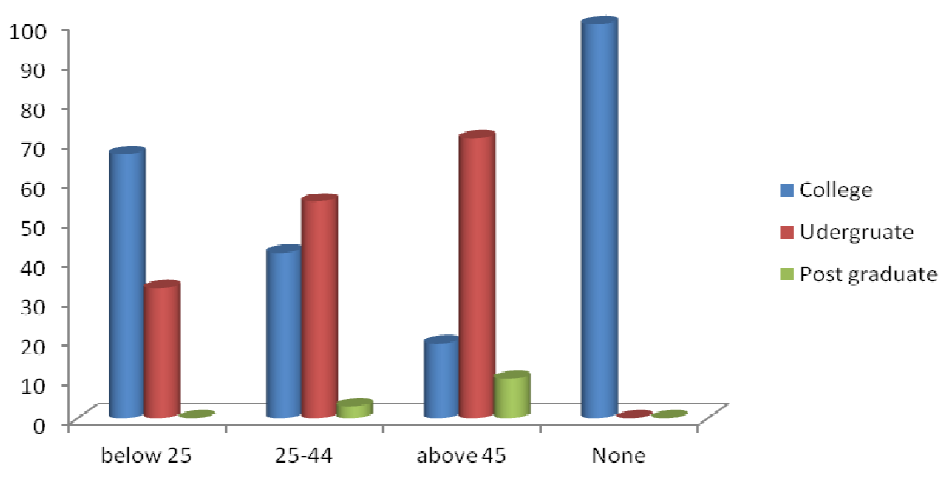

Figure 2: Showing the age and academic qualifications of respondents.

Source: Research Data (2012). (None indicates the respondents who did not give information on their ages and academic qualifications).

Analysis of the academic qualifications and ages of respondents indicate that, more than half $(57 \%)$ of the total respondents had undergraduate academic qualifications, 39\% of them had college qualifications, while $4 \%$ had post graduate qualifications. Majority $(82 \%)$ of the respondents were aged between $25-44$ years, $55 \%$ of this category had undergraduate academic qualifications and $42 \%$ of them had college qualifications, while $3 \%$ of them had post graduate academic qualifications. $16 \%$ of the total respondents were aged above 45 years old with $71 \%$ of them having undergraduate qualifications, $19 \%$ of them had college qualification, while $10 \%$ of them had post-graduate academic qualifications. Two respondents did not indicate their ages and academic qualifications (indicated as None in the analysis). The mean age category was age group 25-44 years old, with a coded mean of 1.16 only. 
Table 1: Respondents' years of service and being a member at the SACCO

\begin{tabular}{llll}
\hline Years of service & Freq & Percent & Cumulative percent \\
\hline Below 1 year & 1 & 0.27 & 0.27 \\
1-5 years & 108 & 29.19 & 29.46 \\
Above 6 years & 261 & 70.54 & 100 \\
\hline Total & 370 & 100 & \\
\hline
\end{tabular}

Source: Research Data (2012)

From Table 1 it was observed that $70.54 \%$ of the respondents had been members for over 6 years, $29.19 \%$ between 1 - 5 years, while $0.27 \%$ below 1 year.

Table 2: Respondents' income in Kshs. per month

\begin{tabular}{clll}
\hline What is your income per month & Frequency & Percent & Cumulative percent \\
\hline $0-10000$ & 11 & 2.97 & 2.97 \\
$10000-20000$ & 42 & 11.35 & 14.32 \\
$20000-30000$ & 131 & 35.41 & 49.73 \\
$30000-40000$ & 137 & 37.03 & 86.76 \\
$40000-50000$ & 46 & 12.43 & 99.19 \\
above 50000 & 3 & 0.81 & 100 \\
\hline Total & 370 & 100 & \\
\hline
\end{tabular}

Source: Research Data (2012)

A look at the respondents' monthly income shows that most of the respondents were in the income bracket of Ksh. 20000 to 40000 per month. Out of all the respondents, $37.03 \%$ had a monthly income of between Ksh. 30,000 and $40,000,35.41 \%$ between Ksh. 20,000 and 30,000, 12.43\% between Ksh. 40,000 and 50,000 only. Both extremes had fewer respondents, with those with monthly income not exceeding 10000 being only $2.97 \%$, while only $0.81 \%$ of the respondents had income of above Ksh. 50,000 only.

\section{Establishing Effect of Commercial Bank Loans on SACCO Financial Performance}

In order to understand the effect of the loans from commercial banks, $t$-test was done and from the test, correlation between the yearly turnover and the loan granted was conducted at $95 \%$ confidence interval using paired $t$ test. A $p$ value of 0.004 was obtained implying that the financial performance of the SACCO was not affected by the commercial bank loans. This could be supported by the fact that over the year's indicators like membership, savings and even the share capital increased statistically.

\section{Determining Effect of Commercial Banks Loans on SACCO Savings and Lending Volumes}

To determine the way loans offered by commercial banks affected the savings and lending volumes of the SACCO, trends of savings for five consecutive years was analyzed as shown below. 


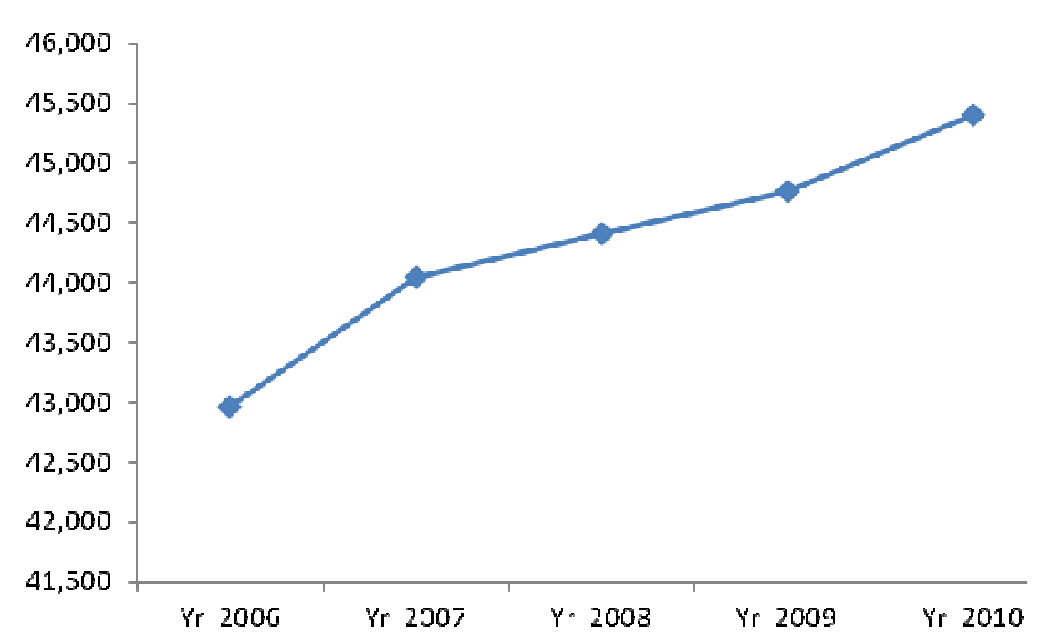

Fig. 3: Trend of SACCO savings.

It was observed that savings improved steadily over the years as the SACCO increased its membership. This shows that the SACCO is growing and is a positive implication for the SACCOs performance.

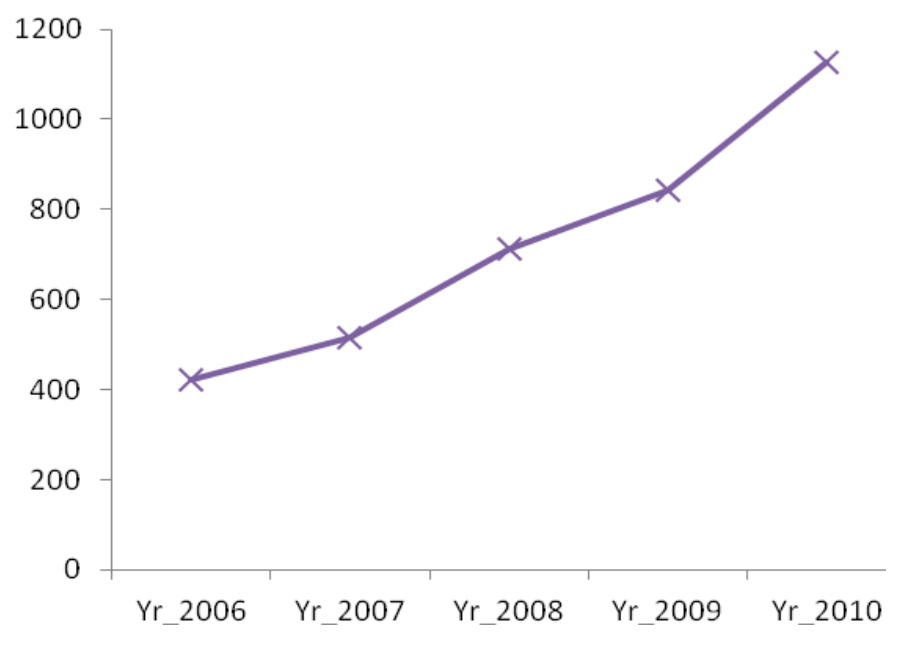

Fig. 4: Trend of SACCO turnover. Source: KUSCO (2010).

It is clear from the chart that the volumes of turnover increased as the savings and membership increased implying increased loans given to members.

Individual Member Benefit from Competition between Commercial Banks and SACCOS

Table 3: Reported Ease of Obtaining Loans from SACCOs

\begin{tabular}{llll}
\hline Ease of obtaining a loan & Frequency & Percent & Cumulative percent \\
\hline Agreed & 167 & 45.14 & 45.14 \\
Disagreed & 97 & 26.57 & 71.35 \\
Neutral & 65 & 17.57 & 88.92 \\
Strongly disagreed & 1 & 0.27 & 89.19 \\
Strongly agreed & 24 & 6.49 & 95.68 \\
Strongly disagreed & 14 & 03.78 & 99.46 \\
Strongly disagreed & 2 & 0.54 & 100.00 \\
\hline Total & 370 & 100 &
\end{tabular}

Source: Research Data (2012) 
The ease of obtaining loans from the SACCO was analyzed and it emerged that, $45.14 \%$ of the respondents agreed that it was easy to obtain loan from the SACCO, $26.57 \%$ of them disagreed that it was easy to get a loan from the SACCO. This could imply that the competition effect has improved the ease of getting loan from the SACCO.

Table 4: Pro-Rata Requirements by SACCO to Provide Loan Services

\begin{tabular}{llll}
\hline Ease of obtaining a loan & Frequency & Percent & Cumulative percent \\
\hline Limited & 222 & 60.00 & 60.00 \\
Neutral & 64 & 17.30 & 77.30 \\
Not limited & 84 & 22.70 & 100 \\
& 370 & 100 & \\
\hline Total & 340
\end{tabular}

Source: Research Data (2012)

When responding to the SACCO requirements and ease of obtaining loans, more than half $(60 \%)$ of the respondents reported that there were limited pro-rata requirements when one wants a loan from the SACCO. $17.30 \%$ of them were neutral about the decision and $22.70 \%$ of them said there were still a lot of requirements when one wants a loan from the SACCO.

Table 5: Perception of Time Taken to Process Loans from SACCO Compared to Banks

\begin{tabular}{llll}
\hline $\begin{array}{l}\text { Processing a loan from SACCO faster } \\
\text { than banks, N=370 }\end{array}$ & Frequency & Percent & Cumulative percent \\
\hline Agreed & 141 & 38.11 & 38.11 \\
Disagreed & 105 & 28.38 & 66.49 \\
Neutral & 53 & 14.32 & 30.81 \\
Strongly agreed & 40 & 10.81 & 91.62 \\
Strongly disagreed & 31 & 8.38 & 100.00 \\
\hline Total & 370 & 100 & \\
\hline
\end{tabular}

Source: Research Data (2012)

From the responses on perception of the time taken to process a loan from SACCO compared to a loan from banks, it was found out that a reasonably large number feel that processing loans from the SACCO is slower than from banks. However, $38.11 \%$ of the people interviewed believed that it was faster to process a loan request from the SACCO as compared to banks against the $28.38 \%$ of them who felt that it was not faster. $14.32 \%$ of the people interviewed were not sure as to whether there was a difference between the speed of processing a loan from the two financial institutions.

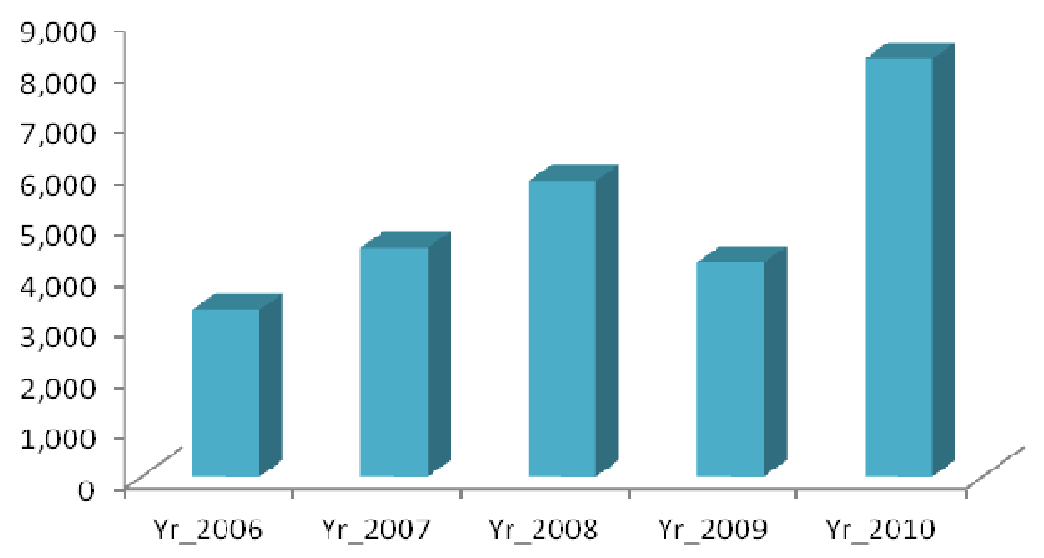

Fig. 4: Trend of loans granted by SACCOs from 2006 to 2010. Source: KUSCO (2010)

The loans granted by SACCO to its members over a period of 5 years from 2006 to 2010 had generally increased. The graph shows a steady increase between 2006 and 2008 and a slight drop in 2009, and then the figure shot up in the year 2010. This shows benefits that members of the SACCO obtained from the SACCO as a result of competition from other financial institutions. 
Table 6: Perceptions of Commercial Banks Offering Longer Loaning Period to Customers

\begin{tabular}{llll}
\hline $\begin{array}{l}\text { Commercial banks offer longer period for } \\
\text { loans, } \mathrm{N}=370\end{array}$ & Frequency & Percent & Cumulative percent \\
\hline Agreed & 119 & 32.16 & 32.16 \\
Disagreed & 61 & 15.49 & 48.65 \\
Neutral & 56 & 15.14 & 63.78 \\
Strongly agreed & 77 & 20.81 & 84.59 \\
Strongly disagreed & 57 & 15.41 & 100.00 \\
\hline Total & 370 & 100 &
\end{tabular}

Source: Research Data (2012)

Most of the respondents perceive that commercial banks offer longer period for loans than SACCOs. The analysis shows $32.16 \%$ of the respondents agreed that commercial banks offered longer period for loans than the SACCOs, $15.49 \%$ of the respondents disagreed about this aspect. $15.14 \%$ of the people interviewed were neutral while $15.41 \%$ strongly disagreed that commercial banks offered longer periods to loans. See table below.

\section{Factors Causing SACCO Members to Borrow Money from Financial Institutions}

The factors that drive SACCO members to borrow from other institutions were analyzed as presented in the tables below.

Table 7: Perceptions That Interest Rate Is Not the Only Consideration

\begin{tabular}{llll}
\hline $\begin{array}{l}\text { Interest rates is not the only } \\
\text { consideration, N=370 }\end{array}$ & Frequency & Percent & $\begin{array}{l}\text { Cumulative } \\
\text { percent }\end{array}$ \\
\hline Agreed & 148 & 40.00 & 40.00 \\
Disagreed & 72 & 19.46 & 59.46 \\
Neutral & 65 & 17.57 & 77.46 \\
Strongly agreed & 47 & 12.70 & 89.73 \\
Strongly disagreed & 38 & 10.27 & 100.00 \\
\hline Total & 370 & 100 & \\
\hline
\end{tabular}

Source: Research Data (2012)

Several factors contribute to a person choosing which financial institution to take a loan from. Although interest rate is an important factor in deciding where to take a loan, it is not the only factor considered by those taking loans. The gathered data shows that $40 \%$ of the people interviewed agree that it was not interest rate that one considers to choose a loaning institution. However, $19.46 \%$ of them disagreed with this fact, implying that it was interest rate only that was considered to choose a loaning institution, while $17.57 \%$ of the respondents were neutral about their perception.

Table 8: Perception on Whether Loan Processing Is Faster In Banks than SACCOs

\begin{tabular}{llll}
\hline $\begin{array}{l}\text { Processing loan in banks is } \\
\text { faster than SACCO N=370 }\end{array}$ & Frequency & Percent & $\begin{array}{l}\text { Cumulative } \\
\text { percent }\end{array}$ \\
\hline Agreed & 140 & 37.84 & 37.84 \\
Disagreed & 96 & 25.95 & 63.78 \\
Neutral & 53 & 14.32 & 78.11 \\
Strongly agreed & 50 & 13.51 & 91.62 \\
Strongly disagreed & 31 & 8.38 & 100 \\
\hline Total & 370 & 100 &
\end{tabular}

Source: Research Data (2012)

The general perception is that loan processing is faster from banks than from SACCOs. It was observed that $37.84 \%$ of the respondents agreed that processing a loan by banks was faster than SACCO, $25.95 \%$ of them disagreed while $14.32 \%$ of the people interviewed were neutral about their opinion over this fact.

This results of members of the SACCO selling their SACCO loans to banks as shown in the table 9 below. 
Table 9: Shows those who borrow from banks to offset SACCO loans

\begin{tabular}{llll}
\hline $\begin{array}{l}\text { Have you sold a loan to a bank? } \\
\mathrm{N}=370\end{array}$ & Frequency & Percent & Cumulative percent \\
\hline Yes & 251 & 67.84 & 67.84 \\
No & 119 & 32.16 & 100.00 \\
\hline Total & 370 & 100 & \\
\hline
\end{tabular}

Source: Research Data (2012)

\section{DISCUSSIONS}

According to the Dasalu management consultant reports (2007), the withdrawal by the commercial banks from the rural Kenya in the1990s was a boon and a blessing in disguise to the urban and other rural related SACCOs. It created an opportunity for the sub-sector to establish a strong foothold in savings mobilization and credit provision at affordable interest rates. Gathera (2005) says that today, the relatively strong economic growth as compared to that of the early 1990s has generated more than enough liquidity to the commercial banks. They now have to seek for opportunities in the economy to invest the excess cash. The banks have, therefore, identified a number of investable alternatives among them the SACCO societies.

It was found out that loans offered by commercial banks have not seriously affected the savings and lending volumes of Mwalimu SACCO. This is due to the fact that the savings and loans granted were observed to be increasing over the years. However, in 2008 the amount of loans granted slightly dropped but then increased in the following year. Nevertheless, this drop did not have any effect on the savings and turnover of the SACCO. This was confirmed by Mungai (2006) in his findings during his research on effects of competition on provision of financial services by Mwalimu SACCO; he stated that SACCOs has suffered a blow from competition that has intensified in the recent years. Some of their members have found other avenues for meeting their financial obligations and thus has affected the SACCOs' annual incomes. The researchers further found that members are not willing to leave the SACCO because of its stability. The competing institutions with the SACCO have managed to lure a few members. The situation can change if the institutions in question prove otherwise.

The results also reflected that members have benefited from the competition between the SACCO and commercial banks. This was shown by some of the members responding that it is much easier to obtain a loan from the SACCO than the banks. However, most of the respondents felt that more could be done since banks offered a longer repayment period and most of them were limited by the pro-rata requirements of the SACCOs. This was also noted by Kithuka (2004), during his examination on whether Ukaguzi SACCO experienced delay or non- remittance of SACCO funds by employer and its effects on the ability to pay loans to members to compete with traditional banks. He found out that Ukaguzi SACCO does not have serious problems of SACCO funds. The mild delay by a few employers has not affected performance of the SACCO. However, in spite of that, he stated that the SACCO could do better.

It was also found out that the SACCO members considered a number of factors before borrowing from other financial institutions. Most of the respondents said that interest rate is not the only consideration when sourcing for loans. Most of them preferred banks when in need of large amounts of money since banks offered more money compared to the SACCO and a longer repayment period. Just as it was found in the study by Makoba (1993) who noted that there are several factors that contribute to a person choosing to take a loan from a financial institution, some of the factors that were found out include interest rates, ease in obtaining the loans and the time period required for loan repayment.

In the Annual reports of KUSCO (2008) it was stated that apart from the banks, the Pyramid Schemes became a challenge to the SACCO, some members borrowed loans from SACCO and other financial institutions, promised to get three times the amount invested into the Pyramid Scheme. The SACCO charges $1.7 \%$ interest per month on loan on reducing balance while commercial banks charge about a fixed rate of $18 \%$ per month yet some SACCO members continue to seek credit facilities from commercial Banks consequently reducing their savings and borrowing capacity. As much as the findings show that the savings have increased, it is increasing in a slow rate and not as it is expected since most members of the SACCO survive on loans.

More often than not, members' attitude towards lending considerably affects SACCO's performance too. According to Lumumba (1997) members' attitude regarding the lending policies for SACCO in Kenya is negative. More so in SACCOs where members' were required to look for guarantors before loans were processed.

SACCOs in Kisumu City have potential for growth and better financial performance especially owing to the fact that their members are loyal to them. As much as there are a few hitches here and there, the study has shown that there is still an improvement in the financial performance and that banks have not yet succeeded in negatively affecting the financial performance of the SACCOs in Kisumu City. 


\section{CONCLUSIONS}

Commercial bank loans have not grossly affected the savings and lending volumes of the SACCO, Competition between SACCOs and Commercial banks has helped to uplift the welfare of members of SACCO.

The SACCO has suffered a blow from competition because its members seek other avenues for funds to meet their financial obligations, consequently affecting SACCO's annual income. This is because commercial banks have mostly targeted employer based SACCOs where check off system of loan repayment is applied. However, the financial performance of the SACCO was improving year after year although it is at a slow rate.

\section{RECOMMENDATIONS}

The Kenyan Government through Ministry of Cooperative Development should come up with an Act which can protect SACCOs from competition by giving equal opportunity of acquiring funds to be disbursed to SACCO members.

Loan repayment period should be reviewed and appropriately negotiated with SACCO members so that, they are not attracted to Commercial banks.

Maximum amount of money borrowed by members in SACCOs should not be based on capital shares held by individuals.

\section{REFERENCES}

Burnett J. (1997). Fair Lending and Private Banking, The 1997 ABA Article.

Gathera (2005). An investigation into investment practices of reserve funds in SACCO's Nairobi, unpublished MBA Thesis, University of Nairobi.

GoK (1986). Economic Management for Renewal GrowthSessional Paper No. 4 1986: Nairobi: Government Printer

GoK(2008). Co-operative Societies Act of 12 of 1997. Nairobi: Government Printer.

GoK (2004). Co-operative Societies Act of 12 of 1997. Subsidiary Legislation. Nairobi: Government Press

Kikeri, S., and Nell's (1989). Public Enterprise Reform and Privatization the World Bank Development volume 17 No 5, pp 659-672

Kithuka, J. (2004). An investigation whether Ukaguzi SACCO experienced delays or non remittance from employees, Unpublished MBA Thesis, Kenyatta University.

KUSCO Annual Report (2007). Nairobi: KUSCO.

KUSCO Annual Report (2008). Nairobi: KUSCO.

KUSCO Annual Report (2010). Nairobi: KUSCO.

Lumumba, Martin Omweri. (1997). An investigation on the members attitudes as regards the lending policies for the savings and credit co-operative societies in Kenya: a case study of Mwalimu Savings and Credit Cooperative society limited, Kenyatta University.

Makoba, J. W. (1993). Public Control and Public Enterprise in sub-Sahara Africa. The case of Tanzania and Zambia African Development Vol x VIII, pp.37-59

Mugenda ,O., and Mugenda, M. (1999). Research Methods: Qualitative and Quantitative Approach. Nairobi: Acts Press.

Mungai, J. N., (2006). The effects of competition on provision of financial services by

Mwalimu SACCO. A Case of Thika District. Unpublished Thesis, Kenyatta University

Muturi B. W. (2000). Performance and Sustainability of formal microfinance institutions. A case of Nairobi, Unpublished Master of Science Thesis, Kenyatta University

Ongore, V. O. (2001). Management Responses of the Co-operative sector, the Case of SACCOs in Nairobi, Unpublished MBA Thesis. University of Nairobi

Oyoo, M. O. (2002). Financial Performance of SACCOS before Deregulation: The case of SACCOs in Nairobi, Unpublished Thesis, University of Nairobi 